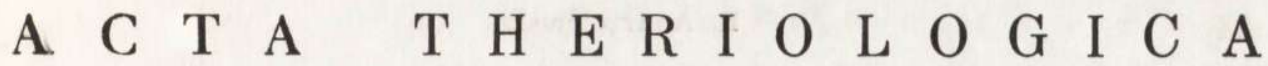 \\ VOL. 20, 2: 23-40. \\ April, 1975
}

Roman A N D R Z E J E W S K I

\section{Supplementary Food and the Winter Dynamics of Bank Vole Populations *}

[With 7 Tables \& 2 Figs.]

The food supply of two populations of Clethrionomys glareolus ( $\mathrm{S} \mathrm{chreber}, 1780$ ): one living in forest on a 4 ha lake island, and the other inhabiting an open forest, was exprimentally increased by supplying oats ad libitum for a period of two years. The food was supplied in wooden boxes, which on the island were arranged in a grid of squares, each $15 \times 15 \mathrm{~m}$. In the open forest the boxes were placed on two plots each of 2.7 ha: (1) intensive supplementation with the grid of boxes $7.5 \times 15 \mathrm{~m}$, and (2) extensive supplementation with the grid of boxes $30 \times 30 \mathrm{~m}$. Population parameters were estimated by the $C M R$ method each individual being marked. Food supplementation caused intensive winter reproduction to such extent that $50 \%$ of individuals found in the spring were born during the winter. On the other hand, food supplementation did not affect winter survival, although a few individuals (females) survived two winters. During the winter, sexually active males were heavier than females. The individuals born during the winter promptly become sexually active. A result of the increased food supply was that the population numbers in the spring were 2 to 4 times higher than in control years. A similar situation was observed in the autumn. Hence the food carrying capacity of the habitat is a significant factor affecting the numbers of small forest rodents despite the fact that, as indicated by energy balance studies, they utilize only a small part of food available in the ecosystem.

\section{INTRODUCTION}

A low degree of utilization of the available food supply in forests by small rodents has been demonstrated by several authors (Gór e cki \& Gębczyńska, 1962; Ryszkowski, 1969; Gębczyńska, 1970; Trojan, 1970; Grodziński, 1971a, b; B a bińska, 1972, and others. This fact may support the opinion that food does not limit directly the numbers of small rodents in fores ecosystems (e.g., G ó-

* Praca została wykonana w ramach problemu węzłowego 09.1.7 koordynowanego przez Instytut Ekologii PAN. 
recki \& Gębczyńska, 1962; Grodziński, 1963, 1970). The reserves of food accumulated during the growing period also exceed the food requirements of rodents during the winter (A u la k, 1973), even at its final stage when the balance between consumption and food supply is least favourable ( $\mathrm{Grodzinski,} \mathrm{1961).} \mathrm{Hence} \mathrm{attempts} \mathrm{have}$ been made to find out factors regulating numbers of rodents in forests (and also in other habitats) by taking into account paratrophic ecological relationships. For example in populations of the bank vole, Clethrionomys glareolus (S chreber, 1970) attention has been drawn to self-regulation of the population numbers by the social and spatial regulation of reproduction (B uja ls ka, 1970, 1971, 1973), or due to the occurrence of competitive species ( $\mathrm{K}$ ošk in a, 1967; A r is tova, 1970).

Attempts to ascertain the effect of food supply on the population numbers of small rodents by supplying additional food in the natural environment does not provide unequivocal answers. Krebs \& De L ong (1965) did not obtain any increase of the numbers of Microtus californicus population as an effect of an experimental increase in the food supply. B ender (1959) for Peromyscus leucopus noveboracensis (Fischer, 1829), and Smith (1971) for Peromyscus polionotus (W a g n e r, 1843) observed an increase in the population numbers after supplying additional food. Similarly Fordham (1971) obtained increased population numbers (mainly males) of Peromyscus maniculatus, and he also observed a better survival of juvenile animals, while $\mathrm{W}$ a $\mathrm{t} \mathrm{t} \mathrm{s}$ (1970) reported prolongation of the reproductive period under such conditions for $C$. glareolus and Apodemus silvaticus (Linnaeus, 1758).

The purpose of the present study was to find out whether the experimental augmentation of the food supply during winter for a forest living population of the bank vole would exert any effect on the dynamics of the populations.

\section{METHOD AND STUDY AREA}

The investigations were carried out on two areas. The first one an island 4 ha in area situated in a lake in northern Poland $\left(53^{\circ} 40^{\prime} \mathrm{N}, 21^{\circ} 35^{\prime} \mathrm{E}\right)$. The vole population living there had already been subjected to numerous analyses (B u jalska, Andrzejewski \& Petrusewicz, 1968; Bujalska \& Gliwicz, 1968, 1972; Gliwicz, Andrzejewski, Bujalska \& Petrusewicz, 1968; Petrusewicz, Andrzejewski \& Gliwicz, 1968; Bujalska, 1970, 1971; Mazurkiewicz, 1971, 1972; Andrzejewski \& Rajska, 1972, and others).

The forest covering this island belongs to three phytosociological association: Salici-Franguletum Malc., 1929; Tilio-Carpinetum Traczyk, 1962, and Circeo-Alnetum Oberdorfer, 1953 (Traczyk, 1965). The conditions of life for the bank vole are excellent in this forest as indicated by the relatively high densities of these rodents observed during several years. 
The second area included a 10 ha plot, not limited by any environmental factors, situated in the Kampinoski National Park near Warsaw $\left(52^{\circ} 20^{\prime} \mathrm{N}, 20^{\circ} 50^{\prime} \mathrm{E}\right)$. This area was covered with forets belonging to the following phytosociological associations: Vaccinio-myrtili-Pinetum $\mathrm{K}$ obe $\mathrm{ndz}$ a, 1930, Pino-Quercetum $\mathrm{K}$ oz ., 1925 , T'ilio-Carpinetum typicum $\mathrm{T} \mathrm{r}$ a c z y k 1962, Carici elongatae-Alnetum (W. $\mathrm{K}$ o c h, 1926) R. Tx B odeaux, 1955, and showed a very mosaic mixture of these associations ( $\mathrm{Traczyk}$ \& $\mathrm{Traczyk}, 1965$ ). The population densities of the bank vole observed during several years were 2 to 10 times lower than those on the island (Andrzejewaki, 1963; Mazurkiewicz, 1972).

The island was inhabited solely by the population of bank vole. On the other hand, in the open forest, while this species dominated among small rodents $(90 \%$ of individuals), Apodemus agrarius (Pallas, 1771), A. flavicollis ( $\mathrm{Melchior}$, 1834) and Microtus oeconomus ( $\mathrm{P}$ a 11 a s, 1776) were also found there. On account of their low numbers only the population of bank vole is analysed in the present study.

The experimental increase of food supply depended on a constant administration of oats in suitably situated feeding points. The oats were supplied ad libitum in wooden boxes $30 \times 30 \times 30 \mathrm{~cm}$ covered with roofing-felt and having a hole to allow the rodents to enter. At anyone time the box contained approximately $3 \mathrm{~kg}$ of oats, which were replaced when $50 \%$ had been husked by rodents.
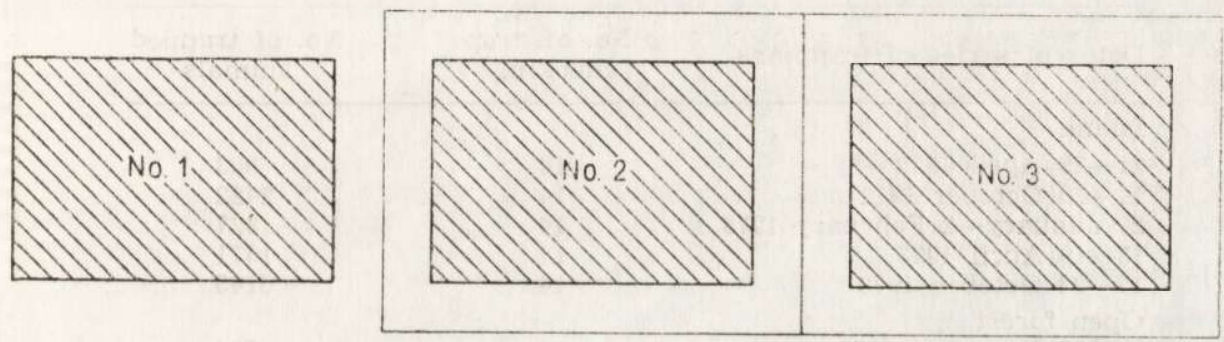

Fig. 1. Diagram of the arrangement of experimental plots in the open area (Kampinoski National Park).

Plot 1 - control; plot 2 - intensive feeding; plot 3 - extensive feeding. The shaded part corresponds to the area of food supplementation and trapping, the marginal non-shaded part is the area of food supplementation without trapping.

The feeding of the animals on the island was organized in a slightly different manner than in the open forest (Kampinoski National Park). The whole island was covered with a grid consisting of 159 feeding points arranged in a checkered pattern at a distance of $15 \times 15 \mathrm{~m}$. In the open forest 3 plots were delineated, each of 2.7 ha. They were situated according to the scheme shown in Fig. 1. Plot 1 served as the control area: 117 boxes were situated in a checkered pattern at a distance of $15 \times 15 \mathrm{~m}$ (9 rows of 13 boxes each). No food was supplied to rodents on this plot. On the other hand, plot 2 for intensive feeding had 247 boxes arranged at a distance of $7.5 \times 15 \mathrm{~m}$ (13 rows, each of 19 boxes). Oats were placed in all of the boxes. Plot 3 , for extensive feeding, was covered with a checkered pattern of boxes situated at a distance of $15 \times 15 \mathrm{~m}$ (13 rows, each 9 boxes), but oats were only placed in every second box arranged linearly - all 
other boxes were used only for the trapping of rodents. Hence the checkered pattern of feeding points had a spacing of $30 \times 30 \mathrm{~m}$, and the whole plot had only 35 such boxes.

The supplementation of the food of the rodents on the island was started in September 1971 and continued without interruption (also in summer) until autumn 1973. The suplementation of food in the open forest began in September 1972 and was stopped in winter 1973 after determining the rodent population.

The changes in the population were estimated by the $C M R$ method (catch, mark, release). For this purpose trapping of rodents on the island was carried out in autumn 1971, spring and autumn 1972 and 1973, and at the end of January 1973. On the unlimited area only one series of trappings was carried out, in February 1973. The numbers of rodents were estimated on the basis of a census of individuals which were trapped at least once in a given series of trappings (except trappings in January 1973, for which the method of the estimation of the numbers in given below) ${ }^{1}$. The details on the periods and time of trapping, as well as on the number of captured rodents are given in Table 1 .

Table 1

Dates of series of trappings, number of trap checking and number of trapped animals.

\begin{tabular}{lcc}
\hline Dates of series of trappings & $\begin{array}{c}\text { No. of. trap } \\
\text { checkings }\end{array}$ & $\begin{array}{c}\text { No. of trapped } \\
\text { animals }\end{array}$ \\
\hline Island & & \\
21-29 April 1972 & 14 & 883 \\
14-20 October 1972 & 14 & 2422 \\
27 January-2 February 1973 & 14 & 827 \\
13-19 April 1973 & 14 & 1671 \\
17-23 October 1973 & 14 & 6145 \\
Open forest & 10 & 594 \\
12-27 February 1973 & & \\
\hline
\end{tabular}

The trappings were carried out by means of live traps open permanently throughout each series of trappings. The rodents were released from the traps every 12 hours, in the morning and evening. The captured individuals were individually marked with numbers by two clipping ( $\mathrm{Na} \mathrm{umov}, 1951)$. The animals were also weighed, their sex determined, and in females opening of the vagina was recorded as the indicator of sexual activity. The number of traps placed in boxes with oats ranged from 3 to 5 , depending on the number of animals in the during a given trapping programme. During trapping the access to oats was rendered impossible. To ensure comparability of the results the traps were placed 15 metres apart whether the boxes were used for food supplementation or not. Thus in the open forest traps were exposed at 117 points on each plot.

In order to reduce accidental trapping of rodents from outside the study plot the traps in the open forest were set only in the central part of each plot, and were surrounded by a $30 \mathrm{~m}$ wide belt of boxes with oats.

${ }^{1}$ Seven day series of trapping are sufficient to catch at least once all the individuals of trapping age on the island ( $\mathrm{Andrzejewski}$ et al., 1967). It can be assumed that this is valid also for the open forest with a lower density of rodents. 
In the studies carried out on the open area a certain number of bank voles were killed and dissected in order to determine the state of their gonads and body fatness. The latter parameter was established by the extraction method of Puzanov, or Badun and Hannon, or Besson ( $\mathrm{M} \mathrm{y} \mathrm{r} \mathrm{cha,} \mathrm{1969).} \mathrm{Since,} \mathrm{on} \mathrm{the} \mathrm{plot} \mathrm{without}$ supplementary food the population numbers were low, some of the rodents for dissection were trapped from the neighbouring forest, since there was no indication that the animals differed from the rodents inhabiting the control plot.

During te numerous investigations carried out on the vole population on the island in the years 1965-1971 some population parameters were determined by the same method as that employed in the present study. This enabled comparison of parameters obtained during supplementary feeding with those in previous years when the island population lived on the natural food supply only.

\section{RESULTS}

\subsection{Reproduction}

On the island, reproduction starts at the beginning of April, and the first young voles reach trappable age in May (B u ja ls k a et. al., 1968). Similarly, in the Kampinoski National Park, reproduction by this species begins in early April (Bujalska \& Ryszkowski, 1966).

Table 2

Number of individuals trapped for the first time and population numbers on the island in April.

\begin{tabular}{lcccccccc}
\hline \multicolumn{1}{c}{ Year } & 1966 & 1967 & 1968 & 1969 & 1970 & 1971 & 1972 & 1973 \\
\hline $\begin{array}{l}\text { No. of trapped for } \\
\text { the first time }\end{array}$ & - & - & - & 4 & 4 & $?$ & 93 & 102 \\
$\begin{array}{l}\text { Population numbers } \\
\text { Po }\end{array}$ & 56 & 68 & 70 & 66 & 29 & $?$ & 141 & 317 \\
\hline
\end{tabular}

During studies carried out on the island in the years 1966-1971, in the spring series of trappings in the second half of April, only voles born (and marked) in the previous year were captured. Single individuals trapped for the first time in April could have crossed to the island over the frozen lake, or exceptionally, have avoided trapping in autumn (Table 2).

April trappings of rodents in 1972 revealed 93 individuals (out of 141) trapped for the first time. Similarly, in April 1973, 102 unmarked individuals were found among a total of 317 trapped (Table 2). This indicates that during those winters when the food supply was experimentally increased, a significant number of new individuals appeared on the island.

In further experiments, the body weights of individuals newly marked in the April trappings were compared with those registered the previous autumn. It was found that the weight distribution was much broader 
than for overwintered animals and that small voles dominated (Table 3).

This suggested that an additional food supply leads to intensive winter reproduction. To confirm this, a trapping programme was carried out on the island at the end of January 1973. Since at that time the snow cover was ca $15 \mathrm{~cm}$ and air temperatures ranged from -8 to $-15^{\circ} \mathrm{C}$, no attempt was made to catch all the so as to avoid the danger of mortality. Despite this, 823 captures of 309 individuals were recorded,

Table 3

Weight structure of the island population of the bank vole. A - overwintered in per cent, B - newly labelled in per cent.

\begin{tabular}{|c|c|c|c|c|c|c|c|c|c|c|}
\hline \multirow{3}{*}{$\begin{array}{l}\text { Year } \\
\text { Body } \\
\text { wt., g }\end{array}$} & \multicolumn{4}{|c|}{ April 1972} & \multicolumn{2}{|c|}{ January 1973} & \multicolumn{4}{|c|}{ April 1973} \\
\hline & \multicolumn{2}{|c|}{ Males } & \multicolumn{2}{|c|}{ Females } & \multirow{2}{*}{$\begin{array}{c}\text { Males } \\
\text { A }\end{array}$} & \multirow{2}{*}{$\begin{array}{c}\text { Females } \\
\text { B }\end{array}$} & \multicolumn{2}{|c|}{ Males } & \multicolumn{2}{|c|}{ Females } \\
\hline & A & B & A & B & & & A & B & A & B \\
\hline$\leqslant 10.0$ & - & 4 & - & 2 & - & - & - & 13 & - & 9 \\
\hline $10.1-15.0$ & - & 14 & - & 12 & - & - & - & 18 & - & 17 \\
\hline $15.1-20.0$ & - & 16 & - & - & 57 & 4 & 1 & 55 & 1 & 35 \\
\hline $20.1-25.0$ & 10 & 27 & 18 & 47 & 37 & 55 & 35 & 12 & 31 & 37 \\
\hline $25.1-30.0$ & 58 & 29 & 76 & 33 & 6 & 39 & 52 & 2 & 66 & 2 \\
\hline$\gtreqless 30.1$ & 32 & 10 & 6 & 6 & - & 2 & 12 & - & 2 & - \\
\hline $\mathrm{N}$ & 31 & 49 & 17 & 49 & 154 & 160 & 120 & 60 & 92 & 43 \\
\hline
\end{tabular}

Table 4

Proportion of females with open vaginae in winter, spring and summer on the island.

\begin{tabular}{cccc}
\hline \multicolumn{2}{c}{ Series of trappings } & $\begin{array}{c}\text { No. of } \\
\text { females }\end{array}$ & $\begin{array}{c}\text { Per cent } \\
\text { of females } \\
\text { with open } \\
\text { vaginae }\end{array}$ \\
\hline April 1972 & Overwintered & 31 & 100 \\
April 1973 & Born in winter & 49 & 86 \\
January 1973 & Overwintered & 121 & 93 \\
October 1971 & Born in winter & 59 & 71 \\
1972 & & 154 & 79 \\
1973 & & 90 & 3.3 \\
& & 241 & 0.4 \\
\end{tabular}

corresponding to $84 \%$ of the total island population. Only one of the individuals captured had not been marked in the autumn series of trappings. On the other hand, $79 \%$ of the females showed open vaginae (Table 4), and some of them appeared to be in advanced pregnancy. Hence the trapping in January 1973 confirmed the occurrence of winter reproduction in the vole population on the island. 
Also the weight distribution of males and females during that period was characteristic. The great majority of the individuals showed a high weight, characteristic for spring, but the weights of the males were significantly higher than those of the females (Table 3).

The effects of increased food supply on winter reproduction were confirmed by trapping in the open forest in February 1973. In agreement with the gradient of intensity of food supply, $90 \%$ of females on plot 2 showed open vaginae and participated in reproduction. On the extensive feeding plot ( $\mathrm{No}_{3}$ ) half of the females participated in reproduction. On the other hand, on the control plot (No 1) open vaginae were found only in $23 \%$ of the females (Table 5). It should be added, however, that the distances between the plots were found to be too small and the home ranges of some individuals included the borders of two plots ${ }^{2}$.

Table 5

Characteristics of the vole population in the open forest in winter 1973.

\begin{tabular}{|c|c|c|c|c|c|}
\hline \multirow{2}{*}{ Item } & & \multicolumn{2}{|c|}{ Food supplementation } & \multicolumn{2}{|c|}{ No additional food } \\
\hline & & $\begin{array}{l}\text { Intensive } \\
\text { plot No. } 2\end{array}$ & $\begin{array}{l}\text { Extensive } \\
\text { plot No. } 3\end{array}$ & $\begin{array}{l}\text { Control } \\
\text { plot No } 1\end{array}$ & $\begin{array}{l}\text { Outside the } \\
\text { control plot }\end{array}$ \\
\hline Population numbers & $\begin{array}{l}\text { Females } \\
\text { Males } \\
\text { Total }\end{array}$ & $\begin{array}{c}65 \\
41 \\
106\end{array}$ & $\begin{array}{c}38 \\
30 \\
68\end{array}$ & $\begin{array}{c}16 \\
9 \\
25\end{array}$ & $\begin{array}{r}10 \\
8 \\
18\end{array}$ \\
\hline Mean body weight, $\mathrm{g}$ & $\begin{array}{l}\text { Females } \\
\text { Males }\end{array}$ & $\begin{array}{l}28 \pm 0.14 \\
25 \pm 0.96\end{array}$ & $\begin{array}{l}25 \pm 0.75 \\
20 \pm 0.93\end{array}$ & \multicolumn{2}{|c|}{$\begin{array}{l}22 \pm 0.62 \\
19 \pm 0.15\end{array}$} \\
\hline $\begin{array}{l}\text { Per cent of females } \\
\text { Length of testes in } n \\
\text { Fat content in } \% \text { of } d r\end{array}$ & $\begin{array}{l}\text { exually active } \\
\text { nm } \\
\text { cy body wt. }\end{array}$ & $\begin{array}{c}90 \\
12 \pm 0.32 \\
18 \pm 0.86\end{array}$ & $\begin{array}{c}53 \\
10 \pm 0.15 \\
20 \pm 0.90\end{array}$ & \multicolumn{2}{|c|}{$\begin{array}{r}6 \pm 0.63 \\
24+1.50\end{array}$} \\
\hline
\end{tabular}

Two individuals weighing $8 \mathrm{~g}$ each were trapped on plot 2 in February. This indicates that their age was around $3-4$ weeks $(\mathrm{Bujalska}$ \& G liwicz, 1968; M a z u rkiewicz, 1972).

Dissection of females showed recent placental scars as well as some pregnancies (quantitative assessment of these data is impossible on account of scanty material). The mean length of testes in males was also in agreement with the gradient of food supplementation (Table 5).

The breeding season on the island, when the population utilized only natural reserves of food, usually ended in October (B u jals ka, 1970). When the food supply was experimentally increased the number of females with open vaginae was also negligible in October (Table 4).

2 Among the remaining rodent species occurring in the open forest all 4 trapped females of $A$. flavicolis had open vaginae, and one out of 2 trapped $M$. oeconomus. This indicates that these species also reacted by reproduction to the additional food supply. 
Hence it can be assumed that in this case food supply was not the principal regulatory factor responsible for the ending of the breeding season.

The period when the individuals born during in winter began to reproduce was also analysed. It was found that in April most of the females born during the winter had open vaginae and hence were sexually active (Table 4). Since the beginning of reproduction on the island in the years of additional food supply occurred on the turn of January and February, the individuals born in winter mature very fast and this greatly increases the reproductive potential of the population at the beginning of the of vegetation growth period i.e. in the second half of April.

\subsection{Survival of Population in Winter}

The winter survival of individuals which were born in the reproduction period preceding a given winter did not increase significantly in spite of the augmented food supply (Table 6). During the first winter with

Table 6

\begin{tabular}{|c|c|c|}
\hline Period & Population number & Survival in $\%$ \\
\hline October 1972 & 504 & - \\
\hline January 1973 & 429 & 85 \\
\hline April $\quad 1973^{1}$ & 215 & 50 \\
\hline
\end{tabular}

1 Only overwintered

food supplementation the survival was similar to the mean of the previous years. During the next winter with food supplementation the survival was higher than in almost all the winters observed on the island (except the first winter 1965-1966), and significantly higher $(0.01<p<0.02)$ than the mean value of these years, but it only slightly exceeded the index of survival found in winters 1966/67 and 1967/68 (by 2 and $4 \%$ ). Thus it appears that winter mortality is not directly regulated by food abundance.

The winter series of trappings carried out in January 1973 made is possible to estimate the mortality rate in the first and second half of winter. The percentage of individuals which survived the first half of the winter in relation to the autumn numbers is significantly higher $(85 \%)$ than the percentage of individuals surviving till spring $(50 \%)$. 
These values refer only to individuals born in the previous year (Table 7) ${ }^{3}$. The collected data do not make it possible to estimate the mortality of individuals born in winter.

During the investigations carried out in the years 1965-1971 among 2316 labelled voles none was known to have survived two winters. In April 1972 one female, No 2019, born in 1970, was trapped. In April two females, No 2277 and 2424 , born in 1971 , were captured. In winter 1973 two females from 1971 were trapped (No. 2314 and 2423). Survival of a second winter may be related to food supplementation, but may

Table 7

Winter survival of the population. Food supply was natural since 1965/66 till 1970/71 and it was increased in $1971 / 72$ and 1972/73. Mean survival with natural food supply $35 \%(N=827)$; with increased food supply $41 \%(N=644)$; Significant difference at $0.02<p<0.01$.

\begin{tabular}{lrrrrrrrrr}
\hline \multicolumn{1}{c}{ Winters } & $1965 / 66$ & $1966 / 67$ & $1967 / 68$ & $1968 / 69$ & $1969 / 70$ & $1970 / 71$ & $1971 / 72$ & $1972 / 73$ \\
\hline \multicolumn{7}{c}{ Number } & in November \\
Total & 118 & 166 & 178 & 224 & 141 & 221 & 145 & 504 \\
Females & 69 & 80 & 102 & 111 & 68 & 107 & 61 & 240 \\
Males & 49 & 86 & 76 & 114 & 73 & 114 & 84 & 249 \\
& \multicolumn{7}{c}{ Survived till April } \\
Total & 56 & 68 & 70 & 67 & 29 & $?$ & 48 & 215 \\
Females & 32 & 31 & 30 & 31 & 16 & $?$ & 31 & 93 \\
Males & 24 & 37 & 40 & 36 & 13 & $?$ & 17 & 122 \\
Total \% & 47 & 41 & 39 & 30 & 21 & $?$ & 33 & 43 \\
\hline
\end{tabular}

also depend on an increased chance of survival occurring in winter $1972 / 73$, or finally may depend on generally high population numbers. However, it can be stated that there exists a physiological possibility of surviving two winters by voles (perhaps this is true only for females).

\subsection{Winter Dynamies of Population Numbers}

The numbers of voles on the island in the autumn in the years 1965-1971 ranged between rather broad limits from 121 to 224 individuals,

3 Of the voles marked on the island in October 60 individuals were not captured in January 1973 but were during the April trapping programme. The mortality of the population from January to April (in the second half of the winter) was calculated only on the basis of the mortality of the individuals captured in January. The total population in January was estimated assuming that, in the second half of the winter, the mortality of individuals which were not captured was similar to those trapped. Hence 309 individuals actually trapped in January plus 60 individuals not trapped in January but trapped in April, plus 60 individuals which did not survive between January and April (a 50\% mortality at that time) but which were probably still alive in January, gives a total number of 429 individuals living on the island in January. 
and the spring number from 29 to 70 individuals (Andrzejewski

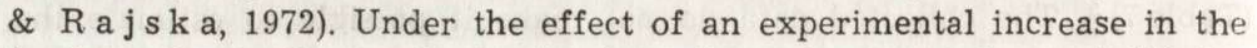
food supply significant changes in these dynamics were observed. Winter reproduction was responsible for the fact that there were 141 animals in the population after the first winter of food supplementation (twice as much as the maximum numbers in the years 1965-1971), including 93 individuals born during the winter. After the second winter the population numbers reached 317 individuals in April (over 4 times more than the maximum value in the years 1965-1971), and included 102 individuals born during the winter (Table 2). Also, in autumn of 1972 (after a full year of food supplementation) there were 504 voles, i.e. twice as many as the maximum number in the years 1965-1971. In

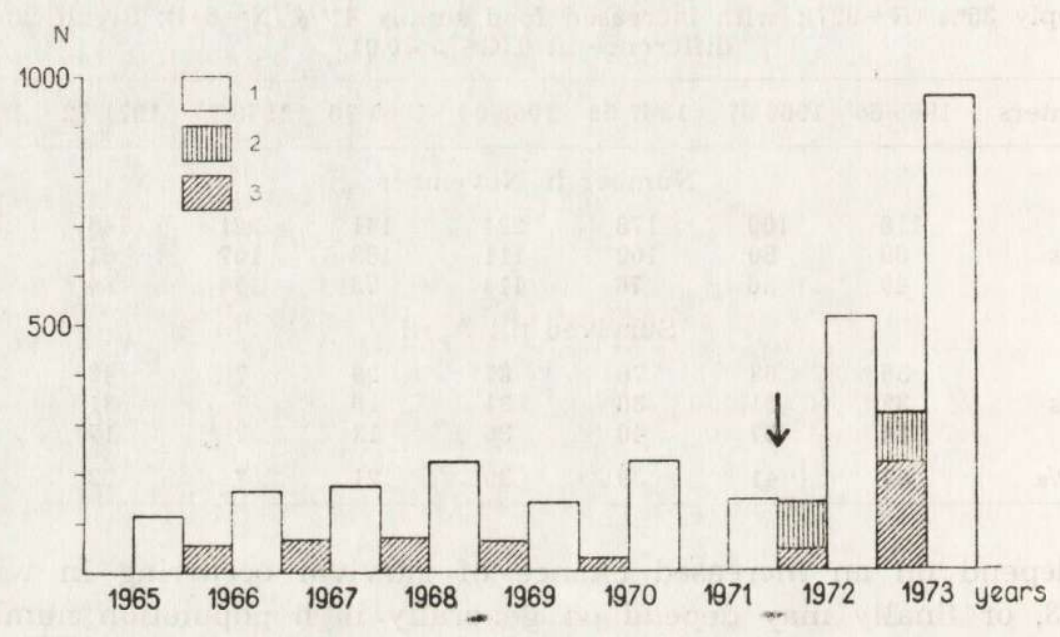

Fig. 2. Population naumber of voles on the island in consecutive years. 1 - autumn population numbers, 2 - spring numbers of individuals porn during winter, 3 - spring numbers of overwintered animals. Arrow - moment of start of food supplementation.

autumn 1973 this figure was as much as 919 individuals, i.e., four times more than the maximum number in the years when the population utilized natural food only (Fig. 2).

In the open forest a gradient of population numbers proportional to the feeding intensity was already obvious during the first winter with food supplementation (Table 5). Since at that time the population did not contain individuals of a trappable age born during the winter (except 2), this gradient was due to migratory processes in the studied area. Food supplementation on this area was started in the autumn when reproduction could not affect the population numbers. Thus it is evident 
that an increased food supply leads to a higher "capacity " of the environment and a greater number of individuals can inhabit a given area.

Hence the result of an increased food supply leads to an increase in the population of voles during the winter due to the accumulation of a higher number of voles in the autumn, to winter reproduction, and also due to increased migration.

\section{DISCUSSION}

The end of March or the beginning of April are generally regarded as the beginning of the reproductive season for the bank vole in Central Europe (B rambell \& Rowlands, 1936; Zejda, 1962; B ergstedt, 1965; Bujalska \& Ryszkowski, 1966; Svyrydenko, 1967; B u j a ls k a, 1971, and others). Some authors however, have mentioned the sporadic occurrence of reproduction of this species during the whole winter, the proportion of reproducing females being already significant in January and February ( $\mathrm{K} \mathrm{u} \mathrm{licke}, 1960 ; \mathrm{Z} \mathrm{e} \mathrm{j} \mathrm{d} \mathrm{a,} \mathrm{1962;}$ K u bik, 1965; S m y th, 1966; S mir in, 1970; K udr ja š ova, 1971, and others). These authors explain the winter reproduction by the voles as being due to the quality and abundance of the supply in favourable climatic conditions.

The results presented in this study confirm the opinion of $\mathrm{W}$ at $\mathrm{ts}$ $(1970)$ on the acceleration of the beginning of the reproductive season in the bank vole as an effect of the experimental increase of the food supply in the habitat. Both in the isolated island and in the open forest the supply of additional food ad libitum causes mass reproduction of the bank vole in January. The arrangement of feeding points in a grid with a spacing of $15 \times 15 \mathrm{~m}$ gives a higher percentage of sexually mature females than does a grid of $30 \times 30 \mathrm{~m}$. Perhaps some of the individuals find access to the food less easy. The size of the home range of the bank vole varies betwene 600 and $3000 \mathrm{~m}^{2}$ (B r ow n, 1965; N a u mov, 1951; S a int Girons, 1960; B e rg s ted t, 1966; R a d d a, 1968; M a zurki ew i c z, 1971, and others). Thus it seems likely that in the employed experimental conditions almost all individuals should find a feeding point within their home range. However, the observed effect may also depend on the social behaviour of the bank vole (Andrzejewski \& Olszewski, 1963; Kikkawa, 1964; Andrzejewski et al., 1967; G I i w i z, 1970 ; and others), in the sense that some individuals occupy feeding foints and do not allow other animals to take food. On the other hand, $\mathrm{Z}$ e j d a (1963) demonstrated that the percentage of females participating in reproduction under conditions of natural food supply 
also depends on its abundance in various plant associations. Anyway in winter, despite relative abundance of food, its quantity seems to be the main factor determining the start of the reproduction period.

The content of fat in the bodies of voles in the open forest was found to be inversely proportional to the intensity of food supplementation (Table 6). Perhaps the animals maintain only a definite conditions when utilizing natural food reserves. The decrease of body fatness in the area with additional food supplementation is related to the occurrence of reproduction during the period in which voles were trapped for fat content analysis.

As demonstrated by Ilyenko \& $\mathrm{Zubčaninova} \mathrm{(1963)} \mathrm{and}$ B e rgsted (1965) under conditions of natural food supply an increase in the body weight of females is observed by the end of winter, that is to say in the period preceding reproduction. The supply of additional food shifts the period of rapid maturation to the first half of winter, and by the end of January the males show the body weights normally found in spring in this population (Bujalska \& Gliwicz, 1968; M a z u rki ew i c z, 1971). A considerable sexual dimorphism in the body weight is characteristic for the beginning of winter reproduction (Table 3 ).

The abundance of the food supply did not appear to be the main factor responsible for the termination of the reproductive season, and in both years this season ended in October, as in the situation in the years without food supplementation (Table 4). The voles born during the winter promptly enter the reproductive cycle and in April most of them participate in it jointly with overwintered animals (Table 4). This causes a considerable increase of the reproductive potential of the population at that period. A similar phenomenon was observed by $\mathrm{Z}$ e j d a (1962) and Kudrjašova (1971) during winter reproduction with a natural food supply.

The survival of the population through the winter with an increased food supply remains on a similar level as when natural food reserves are used (Table 7). This indicated that the reserve of available food offered by the ecosystem for the population in the range from natural conditions to the experimentally increased values in this particular case has no effect on the conditions of life of the voles to such extent as to affect mortality. Hence winter mortality is regulated by some other factors.

The observed cases of survival of a second winter by particular female voles points a physiological ability to live throughout two winters but it is difficult to conclude whether this was a direct effect of food supplementation.

The additional food alters the reproductive season of the voles and 
due to this it increases the population numbers of this species. This is an agreement with the opinion of many authors indicating a relationship between the numbers of a species and food abundance in particular years (M iller, 1954; K ošk in a, 1955; Z e jd a, 1962, 1964; H anss o $n, 1971)$. S m ir in (1970) claims that winter reproduction depends on food reserves but food supplementation has no effect on numbers during the summer. According to the data presented here the population increased due to winter reproduction, as a result of which in spring, the population consists not only of overwintered animals but also of individuals born during the winter. High numbers of voles in spring and prompt sexual maturation of individuals born during the winter lead to a considerable accumulation of individuals until autumn. These high numbers together with winter reproduction result in a particularly high population density in winter, provided that there is a suitable abundance of food (Fig. 2).

A locally increased food supply in open forest also causes an increase in the population density due to immigration.

Several authors observed a low utilization of the potential food supply by rodent populations (Grodziński, 1961, 1971a, b; Górecki \& G ę bczyńska, 1962; R y szkow ski, 1969; G ębczyńska, 1970; Trojan, 1970; Babińska, 1972; Aulak, 1973, and others). For example Buchalczyk et al (1970) showed that Microtus oeconomus (P a 11 a s, 1776) utilizes barely $3.1 \%$ of its food supply but it damages over $60 \%$ of young deciduous trees, out of which 6 to $7 \%$ subsequently die. Estimates of the utilization of food supply do not determine the real effect of a rodent population on this food reserve, neither do they determine the real effect of a natural food supply in the habitat on the population numbers.

The facts discussed above raise certain objections to the suggestion by the International Biological Programme of the existence of energy balances between natural food supply and food requirement of the population as characterizing structural functions in the ecosystems (P e tr us e w ic z \& M a c fadye $n, 1970)$. Despite the fact that rodents utilize their natural food supply to a limited degree the data presented above are in agreement with the opinion of many authors suggesting that population numbers of rodents are in principle regulated by food abundance in the ecosystem, although in a more complicated way than in would appear from the simple energy balance.

Acknowledgements: The author is grateful to Mrs. Anna Ban a ch for the analysis of fat content in the vole bodies. Particular thanks are due to Mr. Krzysztof $\mathrm{Banach}$ and Miss Halina W i e r z bowska for help in the organization of field expeditions and the elaboration of the material, and $\mathrm{Mr} \mathrm{T}$. He aling for revising the English text. 


\section{REFERENCES}

1. Andrzejewski R., 1963: Processes of incoming, settlement and disappearance of individuals and variation in the numbers of small rodents. Acta theriol., 7: 169-213.

2. Andrzejewski R., Fejgin H. \& Liro A., 1971: Trappability of trap-prone and trap-shy bank voles. Acta theriol., 16: 401-405.

3. Andrzejewski R. \& Olszewski J., 1963: Social behaviour and interspecific relations in Apodemus flavicollis ( $\mathrm{M} \mathrm{e} \mathrm{lch}$ i o r, 1834) and Clethrionomys gloreolus ( $\mathrm{S} \mathrm{chreber}, 1780$ ). Acta theriol., 7: 155-168.

4. Andrzejewski R., Petrusewicz K. \& Waszkiewicz-Gliwicz J., 1967: The trappability of Clethrionomys glareolus (S chreber, 1780) and other ecological parameters obtained by the CMR capture method. Ekol. pol. 15: $709-725$.

5. Andrzejewski R. \& Rajska E., 1972: Trappability of bank vole in pitfalls and live traps. Acta theriol., 17: $41-56$.

6. Aristova V. A., 1970: Osobennosti ispolzovanija territorii krasnoj polevki v lesach južnoj časti Kirovskoj oblasti. Mater. Pozn. Fauny i Flory SSRR, Nov. Ser., Otd, Zool. 45(LX), Mater. po gryz., 9: 151-159.

7. A ulak W., 1973: Production and energy requirements in a population of the bank vole, in a deciduous forest of Circaeo-Alnetum type. Acta theriol., 18, 8: $167-189$.

8. B a b i ń s k a J., 1972: Estimation of rodent consumption in a meadow ecosystem belonging to the community of Molinietalia order. Ekol. pol., 20: 748-761.

9. B ende1 J. F.. 1959: Food as a control of a population of white-footed mice, Peromyscus leucopus noveboracensis (F is c h e r). Can. J. Zool., 37: 173-209.

10. B ergstedt B., 1965: Distribution, reproduction, growth and dynamics, of the rodent species (Clethrionomys gloreolus ( $\mathrm{S} \mathrm{ch} \mathrm{reber),} \mathrm{Apodemus} \mathrm{flavicollis}$ (Melchior) and Apodemus sylvaticus (Linné) in southern Sweden. Oikos, 16: $132-160$.

11. Bergstedt B., 1966: Home ranges and movements of the rodent species Ciethrionomys glareolus ( $\mathrm{c} \mathrm{chreber}$ ), Apodemus flavicollis (M l $\mathrm{chior}$ ) and Apodemus sylvaticus ( $\mathrm{L}$ in né) in southern Sweden. Oikos, 17: 150-157.

$12 \mathrm{Brambell}$ F. W. R. \& Rowlands I. W., 1936: Reproduction of the bank vole (Evotomys glareolus $\mathrm{S} \mathrm{chreber).} \mathrm{I} \mathrm{-} \mathrm{The} \mathrm{oestrus} \mathrm{cycle} \mathrm{of} \mathrm{the} \mathrm{female.}$ Phil. Trans. Roy. Soc. Lond., B, 226: $71-87$.

13. Brown I. E., 1956: Movements of some British small mammals. J. anim. Ecol., 25: 54-71.

14. Buchalczyk T., Gębczyńska Z. \& Pucek Z., 1970:: Numbers of Microtus oeconomus (P a 11 a s, 1776) and its noxiousness in forest plantations. EPPO Public., Ser. A, 58: 95-99. Paris.

15. $\mathrm{Bujalska}$ G., 1970: Reproduction stabilizing elements in an island population of Clethrionomys glareolus (S chre be r, 1780). Acta theriol., 15: 381-421.

16. B u jalska G., 1971:: Self-regulation of reproduction in an island population of Clethrionomys gloreolus (S chreber, 1780). Ann. Zool. Fennici, 8: 91-93.

17. Bujalska G., 1973: The role of spacing behaviour among females in the regulation of reproduction in the bank vole. J. Reprod. Fert., Suppl. 19: $465-474$.

18. Bujalska G., Andrzejewski R. \& Petrusewicz K., 1968: Productivity of an island population of Clethrionomys glareolus (S ch r e b e r, 1780). II. Natality. Acta theriol., 13: 415-425. 
19. Bujalska G. \& Gliwicz J., 1968: Productivity investigation of an island population of Clethrionomys glareolus ( $\mathrm{S} \mathrm{ch} \mathrm{re} \mathrm{be} \mathrm{r,} \mathrm{1780).} \mathrm{III.} \mathrm{Individual} \mathrm{growth}$ curve. Acta theriol., 13: 427-433.

20. Bujalska G. \& Gliwicz J., 1972: Growth and reproduction of female bank vole under field conditions. Acta theriol., 17: 33-40.

21. Bujalska G. \& Ryszkowski L., 1966: Estimation of the reproduction of the bank vole under field condition. Acta theriol., 11: 351-361.

22. Fordham R. A., 1971: Field populations of deer mice with supplemental food. Ecology, 52: 138-146.

23. G ę b c z y ńska Z., 1970: Bioenergetics of a root vole population. Acta theriol., 15: $33-66$.

24. Gliwicz J., 1970: Relation between trappability and age of individuals in a population of the bank vole. Acta theriol., 15: 15-23.

25. Gliwicz J., Andrzejewski R., Bujalska G. \& Petrusewicz K., 1968: Productivity investigation of an island population of Clethrionomys glareolus ( $\mathrm{S} \mathrm{chreber}, 1780$ ). I. Dynamics of cohorts. Acta theriol., 13: 401-413.

26. Górecki A. \& G ęb czyńska Z., 1962: Food conditions for small rodents in a deciduous forest. Acta theriol., 6: 275-295.

27. Grodziński W., 1961 Metabolism rate and bioenergetics of small rodents from the deciduous forest. Bull. Acad. Pol. Sci. Cl. II, 9: 439-499.

28 Grodziński W., 1963: Can food control the numbers of small rodents in the deciduous forest? Proc. XV Inter. Congress Zool. Washington.

29. Grodziński W., 1971a: Energy flow through populations of small mammals in the Alaskan taiga forest. Acta theriol., 16: 231-275.

30. Grodzinski W., 1971b: Food consumption of small mammals in the Alaskan taiga forest. Ann. Zool. Fennici, 8: 133-136.

31. Hansson L., 1971a: Estimation of the productivity of small mammals in a South Swedish spruce plantation. Ann. Zool. Fennici, 8: 118-126.

32. Hans on L., 1971 b: Small rodent food, feeding and population dynamics. A comparison between granivorous and herbivorous species in Scandinavia. Oikos, 22: 183-198.

33. I 1 y e nko A. I. \& Z u bčaninova E. V., 1963: Kruglogodičnye nabludenija ze mečenymi ryžimi polevkami i lesnymi myšami v Podmoskove. Zool. Z., 42: $609-617$.

34. $\mathrm{Ki} \mathrm{k} \mathrm{kawa}$ J., 1964: Movement, activity and distribution of the small rodents Clethrionomys glareolus and Apodemus sylvaticus in Woodland. J. anim. Ecol., 33: 259-299.

35. Kolodziej A., Pomianowska I. \& Rajska E., 1972: Differentiation of contacts between specimens in a Clethrionomys glareolus population. Bull. Acad. Pol. Sci. Cl. II, 20: 97-102.

36. Koškina T. V., 1955: Metod opredelenija vozrosta ryžih polevok i opyt ego primenenija. Zool. Ž., 34: 631-639.

37. Koškina T. V., 1967: Vzaimootnošenija blizkih vidov melkih gryzunov i reguljacija ih čislennosti. Mater. Pozn. Fauny i Flory SSSR, Nov. ser., Otd. Zool., 41(LVI), Mater. Gryz., 8: 5-27.

38. Krebs C. T. \& DeLong K. T., 1965: A Microtus population with suplemental food. J. Mammal., 46: 566-573.

39. $\mathrm{Kubik}$ J., 1965: Biomorphological variability of the population of Clethrionomys glareolus (S c h r e be r, 1780). Acta theriol., 10: 117-179. 
40. Ku dr ja š ova L. M., 1971: Podsnežnoje rozmnoženie ryžej polevki v pojmennyh dubravah Okskogo zapovednika zimoj 1967/68. Ekologija, 2: 84-87.

41. Kulicke H., 1960: Wintervermehrung von Rötelmaus (Clethrionomys glareolus), Erdmaus (Microtus agrestis): und Gelbhalsmaus (Apodemus flavicollis). Z. Säugetierkde, 25: 89-91.

42. Mazurkiewicz M., 1971: Shape, size and distribution of home ranges of Clethrionomys glareolus (S chreber, 1780). Acta theriol., 16: 23-60.

43. Mazurkiewicz M., 1972: Density and weight structure of populations of the bank vole in open and enclosed areas. Acta theriol., 17: 455-465.

44. Miller R. S., 1954: Food habits of the wood-mouse, Apodemus sylvaticus ( $\mathrm{L}$ in n e, 1758) and the bank vole, Clethrionomys glareolus (S ch r e be r, 1780) in Wytham Woods, Berkshire. Säugetierkdl. Mitt., 2: 109-114.

45. Myrcha A., 1969: Seasonal changes in caloric value, body water and fat in some shrews. Acta theriol., 16: 211-227.

46. Naumov N, P., 1951: Novyj metod izučenija ekologii melkih lesnych gryzunov. Mat. gryz. 4., Fauna i ekol. gryz.: 3-21, Moskva.

47. Petrusewicz K., Andrzejewski R., Bujalska G. \& Gliwicz J., 1968: Productivity investigation of an island population of Clethrionomys glareolus (S c hreber, 1780). IV. Production. Acta theriol., 13: 435-445.

48. Petrusewicz K., Bujalska G., Andrzejewski R. \& Gliwicz J., 1971: Productivity processes in an island population of Clethrionomys glareolus. Ann. Zool. Fennici, 8: 127-132.

49. Petrusewicz K. \& M a cfadyen A., 1970: Productivity of terrestrial animals. Principles and method. IBP Handbook No 13. Blackwell Sci. Publ.: 1-190. Oxford and Edinburgh.

50. R a d d a A., 1968: Populations Studien an Rötelmäusen (Clethrionomys glareolus, $\mathrm{Schreber}$, 1780) durch Markierungsfang in Niederösterreich. Oecologia (Berl.), 1: $219-235$.

51. Ryszkowski L., 1969: Estimates of consumption of rodent populations in different pine forest ecosystems. [In: "Energy flow through small mammal populations«, Eds. K. Petrusewicz \&. L. Ryszkowski]. Polish Sci. Publ.: 281-289. Warszawa.

52. S a int Girons M. Ch., 1960: Espace vital et comportement territorial chez Apodemus sylvaticus, Clethrionomys glareolus et Microtus agrestis. Relation avec les populations cycliques. Vie et Milieu, 11: 233-260.

53. Smirin J, M, 1970: K biologii melkih lesnych gryzunov v zimnii period. Mater. Pozn. Fauny Flory SSSR, Nov. Ser., Otd. Zool. 45(LX), Fauna i ekologija Gryzunov, 9: 134-150.

54. Smith M. H., 1971: Food as a limiting factor in the population ecology of Peromyscus polionotus. (W a g n e r). Ann. Zool. Fennici, 8: 109-112.

55. S myth M., 1966: Winter breeding in woodland mice, Apodemus silvaticus and voles Clethrionomys glareolus and Microtus agrestis, near Oxford. J. anim. Ecol. 33: 471-485.

56. Svyrydenko P. A., 1967: Rozmnoženije i kolebanije čyslennosti ryžej polevki v uslovijach Ukrainy. Vest. Zool., 1: 9-24.

57. Traczyk H., 1965: The vegetation of "The Wild Apple-Tree Island « on the lake Bełdańskie (North-Eastern Poland). Fragm. flor. geobot., 11: 541-545.

58. Traczyk H. \& Traczyk T., 1965: Charakterystyka fitosocjologiczna terentów badawczych Instytutu Ekologii PAN w Dziekanowie Leśnym (Puszcza Kampinoska) - Phytosociological characteristic of the research areas of the 
Institute of Ecology, Polish Academy of Sciences at Dziekanów Leśny (Kampinos Forest near Warsaw). Fragm. flor. geobot., 9: 547-562.

59. Trojan P., 1970: Energy flow through a population of Microtus arvalis (Pall.) in an agrocenosis during a period of mass occurrence. [In: "Energy flow through small mammal populations«. Eds. K. Petrusewicz \& Ryszkow s k i]. Polish Sci. Publ.: 267-268. Warszawa.

60. W a t t s C. H. S., 1970: Effect of supplementary food on breeding in woodland rodents. J. Mammal., 51: 169-171.

61. Zejda J., 1962: Winter breeding in the bank vole, Clethrionomys glareolus S c hr e b. Zool. Listy, 11: 309-322.

62. Zejda J., 1964: Development of several populations of the bank vole, Clethrionomys glareolus Schreb. in a peak year. Zool. Listy, 13: 15-30.

Accepted, August 28, 1974.

Institute of Ecology,

Polish Academy of Sciences,

Dziekanów Leśny, 05-150 Łomianki, Poland.

\section{Roman ANDRZEJEWSKI}

\section{DODATKOWY POKARM A ZIMOWA DYNAMIKA LICZEBNOSCI POPULAC.JI NORNICY RUDEJ}

\section{Streszczenie}

Celem pracy była próba stwierdzenia, czy eksperymentalne zwiększenie bazy pokarmowej dla populacji nornicy rudej, Clethrionomys glareolus (S chreber, 1870) będzie miało wpływ na jej parametry populacyjne w okresie zimy.

Badania prowadzono na dwóch terenach: na wyspie o powierzchni 4 ha, porośniętej lasem, położonej na jeziorze Bełdany oraz w Kampinoskim Parku Narodowym (KPN). Na wyspie rozstawiono w szachownicy $15 \times 15 \mathrm{~m}$ drewniane skrzynki, w których podawano ad libitum owies. W lesie w KPN założono 3 poletka: (1) intensywnego dokarmiania ( $\mathrm{Nr}$ 2) z szachownicą skrzynek $7,5 \times 15 \mathrm{~m}$, (2) ekstensywnego dokarmiania ( $\mathrm{Nr}$ 3) z szachownicą skrzynek $30 \times 30 \mathrm{~m}$, (3) kontrolne ( $\mathrm{Nr} 1)$, na którym gryzoni nie dokarmianio (Ryc. 1). Dokarmianie na wyspie prowadzono przez pełne 2 lata, w KPN od jesieni do zimowej kontroli populacji. Kontroli parametrów populacyjnych dokonywano przeprowadzając serie połowów zwierząt metodą CMR - wielokrotnego lowienia osobników, które były znakowane indywidualnymi numerami (Tabela 1). Aktywność płciową samic określano na podstawie otwarcia pochwy.

Stwierdzono, że dokarmianie populacji nornicy spowodowało intensywny rozród tego gatunku w zimie (Tabela $2,3,4$ ). Osobniki rozradzające się zimą osiągnęly ciężar, który przy braku dokarmiania uzyskiwany jest dopiero wiosną (Tabela 3). $\mathrm{Na}$ terenie nieograniczonym (w KPN) procent samic biorących udział w rozrodzie był proporcjonalny do intensywności dokarmiania (Tabela 5). Natomiast dokarmianie populacji nornicy nie wpłynęło na okres zakończenia rozrodu przypadający $w$ październiku (Tabela 4). Osobniki urodzone zimą dojrzewają tak szybko, że już w kwietniu biorą udział w rozrodzie wraz z przezimkami (Tabela 4). 
Zimowa przeżywalność populacji nornic nie wzrasta pod wpływem dodatkowego pokarmu (Tabela 7). Przeżywalność w pierwszej połowie zimy jest wyższa niż w drugiej (Tabela 6). Pojawily się jednak pojedyncze osobniki (samice), które przeżyły dwie zimy.

Dokarmianie populacji powoduje istotne zmiany $w$ jej dynamice liczebności (Ryc. 2). Na wiosnę liczebność populacji jest znacznie wyższa niż w sytuacji, gdy populacja żyła kosztem pokarmu oferowanego jej przez ekosystem. Osobniki urodzone zimą włączając się szybko wraz z przezimkami do rozrodu powodują, że na jesieni liczebność populacji przewyższa wielokrotnie liczebność jaką populacja uzyskiwała w okresie przed dokarmianiem. Wysoka liczebność jesienią łącznie $\mathrm{z}$ osobnikami urodzonymi $\mathrm{w}$ zimie zwiększa znacznie zimową liczebność populacji.

Tak więc mimo, że zgodnie $\mathrm{z}$ danymi z literatury, gryzonie wykorzystują swoją bazę pokarmową w nieznacznym stopniu, to powyższe badania pozwalają stwierdzić, że liczebność populacji jest sterowana przez zasobność pokarmową ekosystemu, aczkolwiek w bardziej skomplikowany sposób niż wynikałoby to z bilansu energetycznego między dostępną bazą pokarmową, a zapotrzebowaniem pokarmowym populacji. 